\title{
Identification of the development stage-specific factors in mouse fetal liver binding to the human $\beta$-globin gene promoter $^{1}$
}

\author{
CHEN YADI, YulONG HU, RUOLAN QIAN ${ }^{2}$ \\ Shanghai Institute of Cell Biology, Academia Sinica \\ Shanghai 200031, China.
}

\begin{abstract}
In order to elucidate the molecular mechanisms of globin gene expression during embryonic development, the nuclear extracts from mouse hematopoietic tissue at different stages of development have been prepared. By using DNase I footprinting and gel mobility shift assays, the binding of protein factors in these extracts to the human $\beta$ globin promoter was analyzed. The differences in the binding patterns of protein factors during development were observed. An erythroid-specific and stage-specific nudear protein in the nuclear extract from 18 mouse fetal liver was identified, which can bind to the sequence (from-66bp to -90bp) of human $\beta$-globin promoter. We therefore speculate that the function of this cis-acting element may be similar to stage selector element (SSE) in chicken $\beta^{A}$ - promoter.
\end{abstract}

Key words: $\beta$-globin gene promoter, trans-acting factor.

\section{INTRODUCTION5}

The human $\beta$-like globin genes $\left(\varepsilon,{ }^{G} \gamma,{ }^{A} \gamma, \delta\right.$ and $\beta$ ) are expressed in a temporal and tissue specific fashion. Interaction between stage-specific cis-acting elements and trans-acting factors is important in developmental regulation. However, none

1. Project supported by grants from Shanghai Joint Laboratory of Life Science, Academia Sinica and the National Natural Sciences Foundation.

2. Corresponding author 
of the known nuclear regulatory factors have been shown to influence the temporal specificity of human $\beta$-globin gene expression.

deBoer et al [1] have identified several proteins ( including erythroid and nonerythroid specific proteins ) which can bind to the important regulatory sequences between the cap site and -200 bp of the human $\beta$-globingene. Although NF-E1, an erythroid specific protein, can bind at 2 positions of the upstream promoter (at the -200 region with high affinity and at the -120 region with low affinity), this protein is present throughout development and seems to serve a role in the general activation of erythroid-specific genes rather than in hemoglobin switching.

It is our aim to examine whether some stage-specific elements exist within the promoter region (from-112 to $+20 \mathrm{bp}$ ) of human $\beta$-globin gene. In the present study, we have identified a nuclear protein from mouse fetal liver at $d 18$ of gestation, showing an erythroid and developmental specificity and binding to the human $\beta$-globin promoter at the region from -66 to $-90 \mathrm{bp}$. Our data suggested that this stage-specific trans-acting factor is important in gene regulation during the process of development.

\section{MATERIALS AND METHODS}

\section{Preparation of nuclear extracts}

Nuclear extracts were prepared from K562 cells, mouse fetal liver ( d 10, d 18 of gestation ), $24 \mathrm{~h}$ after birth and adult liver as described by Gorski et al[2]. The nuclear proteins were analyzed, according to the method of Laemmli [3].

\section{Gel mobility shift assay}

Gel mobility shift assays were carried out as described by Strauss and Varshavsky[4], A 5'labeled DNA probe (from -112 to $+20 \mathrm{bp}$ ) was used. Approximately $5 \mathrm{fmol}$ of end-labeled DNA were incubated for $30 \mathrm{~min}$ on ice with 2 to $6 \mu \mathrm{g}$ of nuclear extracts. Poly $\mathrm{dl}$ poly $\mathrm{dC}(1 \mu \mathrm{g})$ was added as a non-specific competitor. DNA-protein complexes were resolved by $4 \%$ non-denaturing polyacrylamide gel electrophoresis.

\section{DNase 1 footprinting assay}

A DNA probe (from -113 to $+20 \mathrm{bp}$ ) was labeled at $5^{\prime}$-end with T4 polynucleotide kinase. The DNase 1 footprinting assay was performed according to the conditions described by Berg et al[5].

\section{RESULTS}

\section{Analysis of nuclear extracts by using polyacrylamide gel electrophoresis}

The nuclear extracts were prepared from mouse hematopoietic tissues at different stages of development and were resolved by electrophoresis with $12 \%$ polyacrylamide gel according to Laemmli[3]. In electrophoretic assay, weobserved that a great number of nuclear proteins from mouse liver at 3 different stages of development (d 10, and d 18 of gestation and $24 \mathrm{~h}$ after birth) was common. However, we could detect at least some proteins which were present only at $d 18$ of gestation (denoted by arrows in Fig 1, lane 3). 
Fig 1. Analysis of nuclear extracts $(5 \mu \mathrm{g})$ by using PAG electrophoresis. Lane 1, Standard (MW). Lane 2, Nuclear extract from d 10 mouse fetal liver. Lane 3, Nuclear extract from d 18 mouse fetal liver. Lane 4, Nuclear extract from mouse liverat $24 \mathrm{~h}$ after birth.

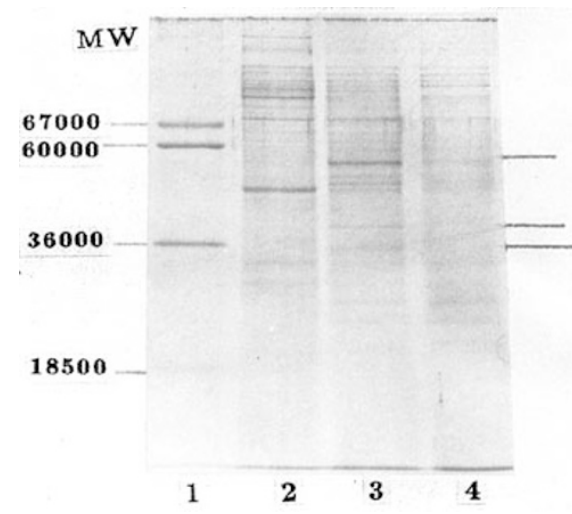

2. Analysis of protein factors binding to the region (from -112 to $+20 \mathrm{bp}$ ) of human $\beta$-globin gene promoter

To investigate the regulatory mechanism of switching of $\beta$-like globin genes, nuclear extracts from mouse liver at different stages of development (d 10 and d 18 of gestation, $24 \mathrm{~h}$ after birth and adult) were analyzed by gel mobility shift assays.

Our data repeatly showed that only one major shift band (band A) could be detected at $d 10$ of gestation (Fig 2, lanes 2 and 3). However, 3 major shift bands ( A, B and C) could be observed at d 18 of gestation (Fig 3, lanes 2-4, Fig 2, lanes 4, 5 ). It was of interest to note that the mobility shift band (band C) was dramatically decreased at $24 \mathrm{~h}$ after birth (Fig 3, lanes 5-7). We therefore suggested that a stagespecific factor may exist in the nuclear extract from d 18 mouse fetal liver. These trans-acting regulatory factors may be important in developmental regulation.

We could not detect any mobility shift band in the nuclear extract from mouse brain (Fig 2, lanes 8 and 9). This result indicated that 3 trans-acting factors (shift bands $A, B$ and $C$ ) were all erythroid-specific. In addition, the binding pattern of protein factors in adults was significantly different from that of other stages ( $d 10$ and $\mathrm{d} 18$ of gestation and $24 \mathrm{~h}$ after birth). In adult stage, the amount of 3 shift bands ( $A, B$ and $C$ ) in mouse liver and spleen was decreased and some new bands were observed (Fig 3, lanes 8-11. Fig 2, lanes 6 and 7). We speculated that these dramatic changes may be due to the shift of erythropoiesis site.

We have also prepared the nuclear extract from K562 cells (human erythroleukemia cell) which normally cannot express $\beta$-globin gene. In gel mobility shift assays, 2 major bands could be detected, which differed from those of mouse fetal liver at $d$ 18 of gestation (Fig 4). It seems likely that the major activator essential for the expression of $\beta$-globin gene is deficient in $\mathrm{K} 562$ cells. 


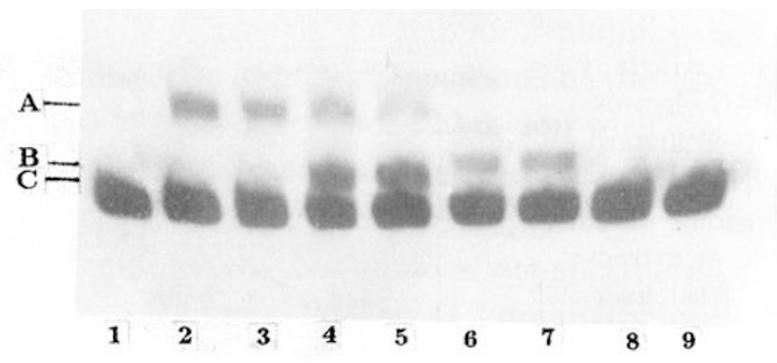

Fig 2. Gel mobility shift assays. The probe (from $-112 \mathrm{bp}$ to $+20 \mathrm{bp}$ ) was 5 -end labeled. Lane 1, Labeled fragment without nuclear extract. Lanes 2 and 3, Labeled fragment with $2 \mu \mathrm{g}$ of nuclear extract from mouse fetal liver at d 10 of gestation. Lanes 4 and 5, Labeled fragment with 2 $\mu \mathrm{g}$ of nuclear extract from mouse fetal liver at $\mathrm{d} 18$ of gestation.Lanes 6 and 7, Labeled fragment with $2 \mu \mathrm{g}$ of nuclear extract from aduIt mouse spleen. Lanes 8 and 9, Labeled fragment with $2 \mu \mathrm{g}$ of nuclear extract from mouse brain.

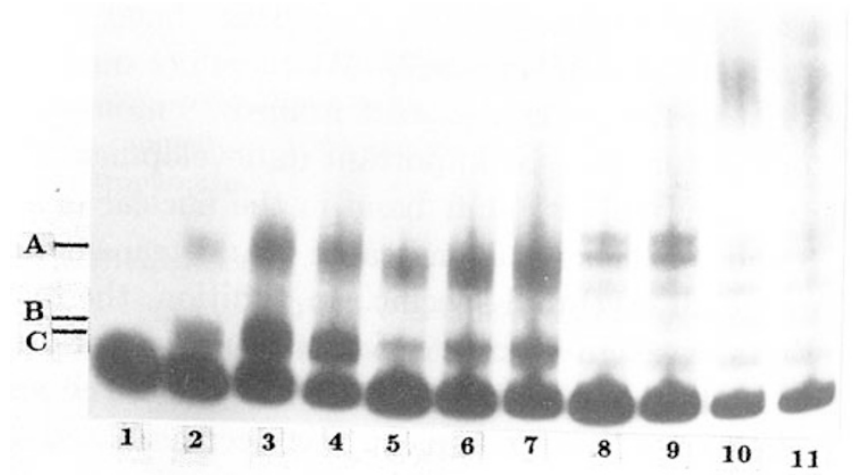

Fig 3. Proteins binding to the region (from $-112 \mathrm{bp}$ to $+20 \mathrm{bp}$ ) of the human $\beta$-globin promoter by using gel mobility shift assays. The probe (from $-112 \mathrm{bp}$ to $+20 \mathrm{bp}$ ) was 5' -end labeled. Lane 1, Labeled fragment without nuclear extract. Lanes 2, 3 and 4 , labeled fragment with 2,4 and $6 \mu \mathrm{g}$ of nuclear extract from mouse fetal liver at d 18 of gestation respectively. Lanes 5, 6 and 7, labeled fragment with 2, 4 and 6 $\mu \mathrm{g}$ of nuclear extruct from mouse liver at $24 \mathrm{~h}$ after birth respectively. Lanes 8, 9, 10 and 11, labeled fragment with $2,4,6$ and $8 \mu \mathrm{g}$ of nuclear extract from adult mouse liver respectively. 
Fig 4. Gel mobility shift assays of the region (from $-112 \mathrm{bp}$ to $+20 \mathrm{bp}$ ) of human $\beta$ globin promoter with nuclear extracts from mouse fetal liver and K562 cells. Lane 1, Labeled fragment with $4 \mu \mathrm{g}$ of nuclear extract from mouse fetal liver at d 18 of gestation. Lane 2, 3 and 4, Labeled fragment with 6,4 and $2 \mu \mathrm{g}$ of nuclear extracts from K562 cells respectively. Lane 5, Labeled fragment without nuclear extracts.

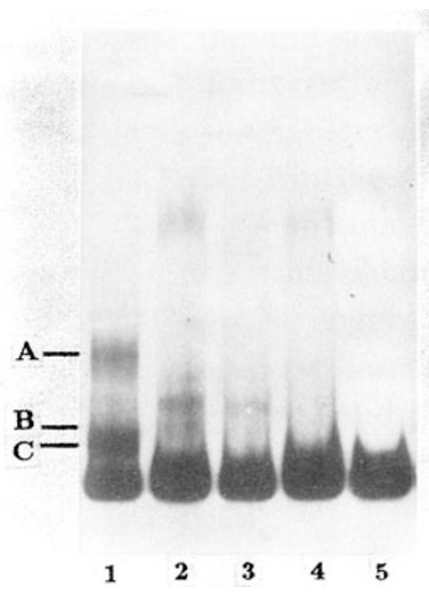

\section{Identification of the protein binding site by DNase 1 footprinting analysis}

In order to localize the cis-acting element responsible for the binding of protein factors, DNase 1 footprinting assay was carried out. We found that the hypersensitive site (HS) could be first revealed at d 10 of gestation even though the protected region could not be detected (Fig 5, lanes 4 and 5). However, a major protected region (from -90 to -66 bp) was observed at d 18 of gestation, and the HS also could be detected (Fig 5, lanes 6 and 7). Interestingly, the HS and the protected region both disappeared at $24 \mathrm{~h}$ after birth (Fig 5, lanes 8 and 9). This protected region contained CAAT box region and CAC box region. It has been demonstrated that there were several binding sites within these regions[1]. However, no stage-specific proteins comparable to those in the chicken system have so far been identified in the human $\beta$-globin gene promoter. From our data, we suggested that there was a stage-specific factor in nuclear extract from d 18 mouse fetal liver, which could specifically bind to the region (from -66 to $-90 \mathrm{bp}$ ) of the human $\beta$-globin promoter.

We considered that the function of this cis-acting element may be similar to SSE (stage selector element) in the chicken $\beta^{A}$ promoter.

\section{DISCUSSION}

To clarify the molecular mechanism regulating differential expression of $\beta$-like globin genes, we have focused on defining the cis-regulatory sequences and transacting factors required for their appropriate tissue and developmental stage-specific expression. Chio and Enge1[6] identified a region of the chicken $\beta^{A}$ promoter termed as stage selector element which was required in transient transfection of definitive erythroid cells for both the expression of adult gene and the suppression of a linked embryonic gene. Two SSE-binding factors ( $\beta$ CTF and NF-E4) were identified; $\beta$ CTF bound to CCAAT box and NF-E4 bound to a purine-rich sequence located between the TATA and CCAAT boxes [7]. 


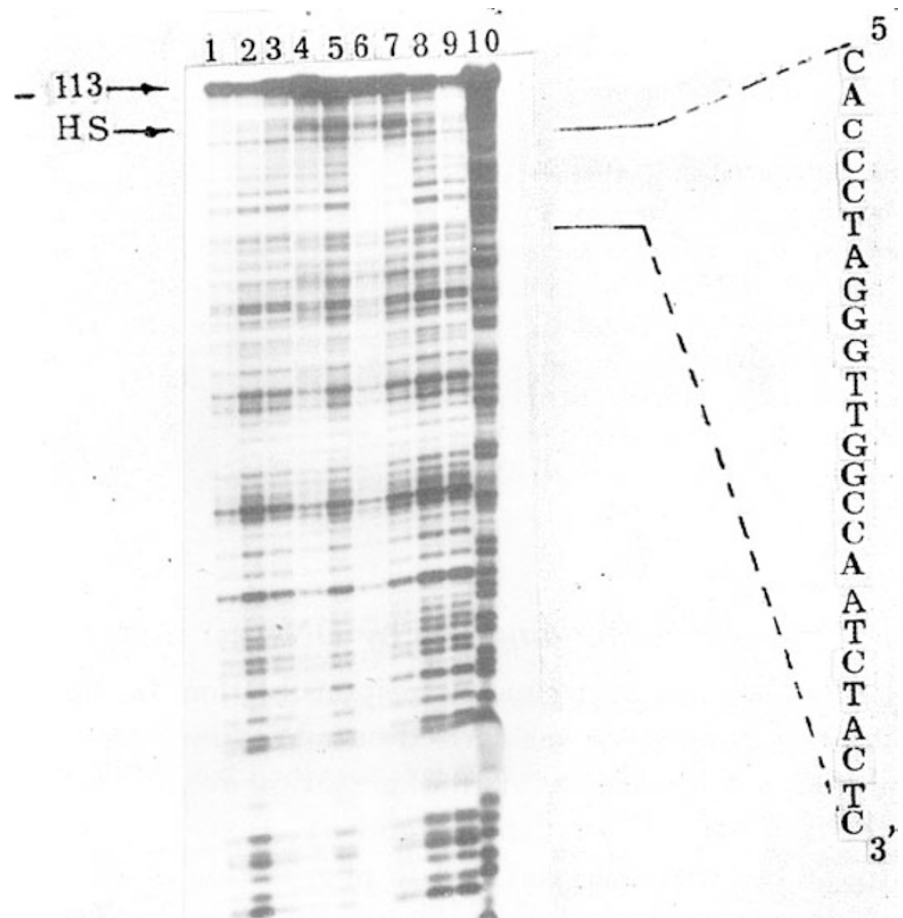

Fig 5. Localization of cis-acting element responsible for the binding of protein factors

The probe (from -113 bp to $+20 \mathrm{bp}$ ) was $5^{\prime}$-end 1abeled. Lanes 1, 2 and 3 Labeled fragment without nuclear extract. Lanes 4 and 5. Labeled fragment with 8 and 12 $\mu \mathrm{g}$ of nuclear extracts from mouse fetal liver at d 10 of gestation respectively. Lanes 6 and 7. Labeled fragment with 10 and $20 \mu \mathrm{g}$ of nuclear extracts from mouse fetal liver at d 18 of gestation respectively. Lanes 8 and 9 . Labeled fragment with 7 and $14 \mathrm{\mu g}$ of nuclear extracts from mouse liver at $24 \mathrm{~h}$ after birth respectively. Lane 10 . $\mathrm{A}+\mathrm{G}$ ladder.

In this paper we have used the mouse system to study the human $\beta$-globin gene expression because mice have a related pattern of developmental switching. During the embryonic life, at $\mathrm{d} 8$ of gestation the embryonic $\beta \mathrm{H} 1$ and $\varepsilon \mathrm{Y} 2$-globin genes began to be expressed in the yolk sac[8-11]. At $d 11$ of gestation, the fetal liver became the major site of erythropoiesis almost up to birth $[12,13]$. The level of $\beta \mathrm{H} 1$ expression was highest at $\mathrm{d} 10$ and $\mathrm{d} 11$ and declined afterward,while the expression of $\varepsilon$ Y2 peaked at about d 13 and decreased during further fetal development. The expression of the adult $\beta$-globin genes (as related to the human $\beta$-globin gene) peaked at about d 18.

The interaction between cis-regulatory sequences and trans-acting factors is important in the developmental regulation. The data on the role of the promoter of human $\beta$-globin gene in the developmental control of globin genes expression have so far been limited. No stage-specific factors have been identified. Using gel mobility 
shift assays we have identified that there is an erythroid-specific and stage-specific factor (shift band C) at d 18 of gestation. Using DNase 1 footprinting assay, a specific footprint (from -66 to $-90 \mathrm{bp}$ ) was also observed at the same developmental stage. From these results of gel mobility shift and DNase 1 footprinting assay, we suggested that a stage-specific cis-acting element (from -66 to $-90 \mathrm{bp}$ ) may exist in the human $\beta$-globin promoter. The binding of a protein factor to this element may be responsible for the expression of the adult- $\beta$-globin gene. We also suggested that the stage-specific regulation of $\beta$-like globin gene switching may be based on the competition between their promoters and enhancers (including distal and proximal enhancers). Answers to this hypothetical suggestion are currently in progress.

\section{REFERENCES}

[1] deBoer E, Antoniou M, Mignotte V, Wall L, Grosveld F. The human $\beta$-globin promoter; nuclear protein factors and erythroid specific induction of transcription. The EMBO J 1988; 7:4203-12.

[2] Gorski k, Carneiro M, Schibler U. Tissue-specific in vitro transcription from the mouse albumin promoter. Cell 1986; 47:767-76.

[3] Laemmli UK. Cleavage of structural proteins during the assembly of the head of bacteriophage T4. Nature (London) 1970; 227:680-5.

[4] Strauss F, Varshavsky A. A protein binds to a satellite DNA repeat at three specific sites that would be brought into mutual proximity by DNA folding in the nucleosome. Cell 1984; 37:889-901.

[5] Berg PE, Williams DM, Qian RL, et al. A common protein binds to two silencers 5' to the human $\beta$-globin gene. Nucleic Acids Res 1989; 17:8833-52.

[6] Choi O-RB, Engel JD. Developmental regulation of $\beta$-globin gene switching. Cell 1988; 55:17-26.

[7] Gallarda JL, Foley KP, Yang Z, Engel JD. The $\beta$-globin stage selector element factor is erythroid-specific promoter/enhancer binding protein NF-E4. Gene \& Dev 1989; 3:1845-59.

[8] Fantoni AA, DeLa Chapelle, Rifkind RA, Marks PA. Erythroid cell development in fetal mice: synthetic capacity for different proteins. J Mol Biol 1968; 33:79-91.

[9] Fantoni AA, DeLa Chapelle, Marks PA. Synthesis of embryonic hemo-globins during erythroid cell development in fetal mice. J Biol Chem 1969; 244:675-81.

[10] Farace MG, Brown BA, Raschella G, Alexander J, Gambari R, et a1. The mouse $\beta$ h1 gene codes for the $\mathrm{Z}$ chain of embryonic hemoglobin. J Biol Chem 1984; 259:7123-8.

[11] Hansen JN, Konkel DA, Lader P. The sequence of a mouse embryonic $\beta$-globin gene. J Biol Chem 1982; 257:1048-52.

[12] Rifkind RA, Chui D, Epler H. An ultrastructure study of early morphogenetic events during the establishment of fetal hepatic erythropoiesis. J Cell Biol 1969; 40:343-65.

[13] Whitelaw E, Tsai SF, Hogben P, Orkin SH. Regulated expression of globin chains and the erythroid transcription factor GATA-1 during erythropoiesis in the developing mouse. Mol Cell Biol 1990; 10:6596-606.

Received 2-7-1993. Revised 15-19-1993. Accepted 17-11-1993. 